\title{
Editorial
}

\section{Thinking Development from an Interdisciplinary Perspective}

\author{
Tennyson Mgutshini \\ Denzil Chetty \\ Vaneshree Govender
}

Post-1994 saw a transformation and restructuring of the higher education landscape in South Africa. In 2001 the Ministry of Education published a National Plan for Higher Education in South Africa, intending to "redress past inequalities and to transform the higher education to serve a new social order, to meet pressing national needs, and to respond to new realities and opportunities" (Ministry of Education 2001: 4). This transformation agenda drew its objectives from the Education White Paper 3 (1997: 3-4), which was threefold:

1. To address the development needs of society and provide the labour market, in a knowledge-driven and knowledge-dependent society, with the ever-changing high-level competencies and expertise necessary for the growth and prosperity of a modern economy.

2. To contribute to the socialisation of enlightened, responsible, and constructively critical citizens.

3. To contribute to the creation, sharing, and evaluation of knowledge.

As a result, two notable shifts occurred in the higher education landscape. The first shift was the consolidation of historically white universities with disadvantaged black universities. The second shift saw the firm establishment of technikons within the higher education landscape as "universities of technology" (cf. Republic of South Africa 1997; and Republic of South Africa 2003). However, almost two decades have passed, yet the relationship between 
traditional universities and the recently founded universities of technology has not fully materialised in terms of the three knowledge-driven purposes identified above. To a great extent, both spheres of higher education continue its historical distinctiveness with very little collaboration between each other.

In order to address this historical anomaly, this special issue of Alternation marks an inaugural collaboration between the University of South Africa (Unisa) and the Durban University of Technology (DUT). The purpose of this collaboration is to transcend the historical boundaries of knowledge production by creating a joint interdisciplinary discourse space. The rationale behind such collaboration is to build an enhanced set of research competencies to produce contextually-relevant knowledge for consumption by public and private spheres. This special issue of Alternation is the result of a two-year journey commencing in 2018. The two year period included a conceptual workshop, which focused on the framing of the theme of this special issue and collaboration; and a series of publication for writing workshops, which saw the transfer of critical research writing skills.

In rethinking the role of higher education within the scope of the three objectives articulated in the Education White Paper 3 (1997: 3-4), the guest editors for this collaboration decided to premise its inaugural knowledge production project on "Thinking Development from an Interdisciplinary Perspective". The term "development" is an interdisciplinary concept, which allows for critical-cross discipline interrogation. This special issue explores the notion of development through four sub-themes, vis-à-vis (1) economics, (2) politics, (3) education, and (4) governance and political economy (cf. figure 01 below).

Why development? In his seminal work on The Concept Development, Amartya Sen (1988: 23) argued that:

The concept of development is by no means unproblematic. The different problems underlying the concept have become clearer over the years on the basis of conceptual discussions as well as from insights emerging from empirical work.

This statement resonates well with the notion of development in the African continent. In her article entitled Development of Human Capital for Industrialisation: Drawing on the Experiences of Best Performers, Theresa Moyo (2018: 107) argued that for Africa to achieve its industrialisation goal as 
articulated in Agenda 2063, the Action Plan for the Industrial Development of Africa (AIDA), and the Sustainable Development Goals 2030, a transformative approach to human capacity development must be a top priority. Eric E Otenyo (2018) argued that development by itself, conjures economic performance of activities, but the political determinants of these activities are also imperative. Both these statements by Moyo and Otenyo demonstrate the complexity of unpacking the notion of development in the African context.

(1) ECONOMICS

(2) POLITICS

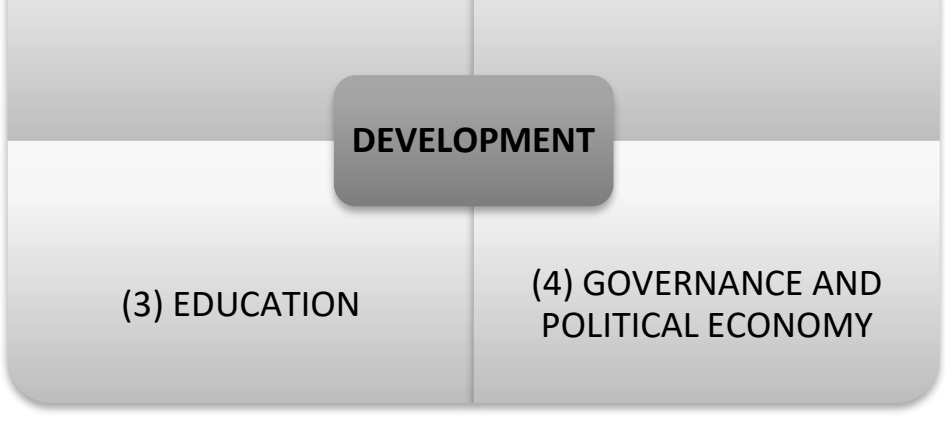

Figure 01: Sub-themes of this special issue

Therefore, this special issue of Alternation draws on empirical case studies, explorative narratives, contextual problematisations, and critical theories to explore the intersections of development with economics, politics, education, and governance and political economy.

The guest editors of this special issue would like to acknowledge the mentoring of Professor Johannes A Smit (Editor-in-Chief of Alternation), with his critical guidance in shaping this inaugural collaboration between Unisa and DUT, as well as his insights in shaping this interdisciplinary discourse space. This publication is the first issue in a series of planned publications over the next five years between Unisa, DUT, and Alternation.

The following section provides a synopsis of the papers in this special issue of Alternation. 
The legacy of apartheid lives on in democratic South Africa, as evidenced by the high rates of unemployment, inequality, and poverty that are prevalent in the country. Almost 3 million youth between the ages of 18 and 24 are disengaged from education, training, and employment. The Post School Education and Training system in South Africa is tasked to engage these young adults through availing programmes that empower them with functional skills required in the labour market and to engage in entrepreneurial activities. However, the post-school system is riddled with challenges related to the delivery and implementation of policies intended to redress the educational inequalities that were created during the pre-democratic era. One major challenge relates to the inadequate delivery of learning programmes that enable vertical or horizontal learner progression or articulation and also promote career development in all sectors of the economy. The challenge that prevents most people from articulating from education and training institutions to the workplace or entrepreneurial activity may be driven by structural elements related to the labour market and the education system.

Titled, 'Enabling Articulation for Entrepreneurial Development through Private-Public Partnerships' by Bertha Sibhensana, Savathrie Maistry, Darren Lortan and Tennyson Mgutshini a qualitative study was conducted in the footwear and leather sector to identify some of the challenges facing the education system. The primary aim of the study was to explore how entrepreneurial readiness can be promoted through a partnership between industry, government, and the post-school system. Interviews with research participants focussed on establishing the extent to which the education and training offered at Centres of Footwear Entrepreneurship prepared graduates for further study and entrepreneurship. The study revealed that articulation as a driver for entrepreneurial readiness and skills acquisition could be thwarted by; financial insecurity of students, the nature of the delivery of programmes, failure to meet minimum requirements for learning programmes and fear of failure. The post-school education system should promote articulation with a view to foster entrepreneurial readiness among graduates as entrepreneurship is key in dealing with the unemployment challenge.

The characteristics of family and non-family owned small and medium enterprises (SMEs) have an inherent impact on managerial decisions that are likely to affect firms' innovation performance. Titled, 'Differences in Innovation Performance between Family and Non-family Owned Manufacturing Small and Medium Enterprises (SMEs) in KwaZulu-Natal' by Gustave 
Mungeni Kankisingi and Shepherd Dhliwayo, this study attempts to determine the differences in innovation performance between family and nonfamily owned businesses. The study was quantitative and used a crosssectional survey design to collect data from owner-managers of a sample of 308 SMEs. The study found that there was a significant difference in innovation performance between family-owned and non-family owned SMEs. Non-family owned firms were found to be more innovative than family-owned firms, as they were more likely to make effective decisions with regards to the launch of new products, business processes, positioning in the market as well as the choice of business models. The type of ownership is, therefore, likely to influence the innovation performance posture of SMEs. The study recommends managers of family-owned firms to deliberately encourage and empower family members to adopt an entrepreneurial orientation in order to enhance innovation performance in their organisations. In addition, when creating databases, public and private agencies must categorise SMEs as family and non-family owned in order to facilitate future-focused analyses.

The study by Mathew Kimweli Kimanzi is titled, 'Sustainable Business Practises: A Case of Pietermaritzburg-based Small and Medium Enterprises'. South Africa is a country committed to accomplishing the Sustainable Development Goals (SDGs) by the year 2030. These goals are a universal call to action to end poverty, protect the planet, and ensure that all people enjoy peace and prosperity. For this to be achieved, it is the responsibility of all stakeholders to take an active role in ensuring that they act in sustainable ways towards the environment and society. However, the role of SMEs in sustainable development in developing countries has always been neglected, as it is deemed that they are not big enough to affect any climatic and social changes. This study investigated environmental and workplace sustainability practices by SMEs in South Africa. Primary data was collected from SME owners and managers in the Pietermaritzburg area of Kwa-Zulu Natal, South Africa, by means of self-administered questionnaires $(n=182)$. It was established that SMEs are taking actions to reduce their carbon footprint and providing safe environments for their employees. The study also established that environmental reporting and HIV/AIDS management was not being prioritized by the SMEs. SMEs are urged to prepare environmental reports that articulate the actions they are taking in order to attract funding from impact investors. Building a healthy workforce through investment in HIV/AIDS management programs could help strengthen the performance of the SMEs. 
In 'The Rule of Law as a Pre-requisite for Public Policy Implementation: The Case of Free Basic Water Service Delivery in Ingquza Hill Municipality, C.N. Mohamed Sayeed and Q. Matha focused their research on the stimulus for service delivery transformation in South Africa. Service delivery transformation has been through a myriad of new service delivery policies that identify targets, responsibilities, and provide for the creation of new institutional mechanisms that seek to restore balance. While much has changed, twenty-five years into democracy, South Africa remains a highly polarised society, with one of the highest levels of income inequality in the world. Within the context of good governance, considering the role of the rule of law in ensuring that equitable delivery of services takes place through policy implementation, is critical. This paper seeks to examine the relevance of the rule of law in the context of service delivery policy implementation and reflects on the case of Free Water Service delivery in Ingquza Hill Local Municipality, a rural area in South Africa. The paper concludes that while governance mechanisms provide clear guidelines for the rule of law and how policy ought to be implemented, the implementers of policy have poor policy knowledge, which in turn impacts on the extent to which the gap between the haves and have-nots can be closed. Within the context of this case study, the principles of the rule of law, namely, legality, equality, and acknowledgment of the rights of citizens, are being fettered. Unequal access to water persists despite the prevalence of the rule of law. The article concludes by calling for a transition beyond the elements of good governance towards a capable state.

In their 'Human Capital Development for Public Governance in South Africa', Bongeka Nkwanyana and Sybert Mutereko assert that the capacity of the public sector lags far behind public expectations, and critical skills gaps remain a challenge in many areas. They argue that to achieve the goals of a developmental state, the public service should be skilled appropriately and capable of delivering quality services efficiently. A skills shortage and constrained capacity in the public sector have a detrimental effect on service delivery. The South African democratic transition in 1994 saw the implementation of public sector reforms in all spheres of government. Training and development were embraced as a transformation strategy supported by both policy reform and funding. Unfortunately, there is little evidence of the effectiveness of this training. Drawing on a case study of a government department in the KwaZulu-Natal province in South Africa, this study sought to understand the factors that influence the effective implementation of training 
and development. Using in-depth interviews, surveys and documentary evidence, this paper reveals a limited budget for training and development in the department. Furthermore, the study established that the money budgeted for training was reallocated to other operational activities due to governmentwide austerity measures. These findings have profound implications for policymakers as well as human resources development practitioners as they provide important insights into the reasons for the infectiveness of the training and development programme in the South African public sector.

Commoditisation, materialism and religious exchange have been receiving increasing attention in contemporary Pentecostal Christian churches, noting that some believers advocate that there is a price to pay in Christianity. This may be a reflection of social development, a new form, but it appears to be an old form of the practice of both secular and spiritual. In his empirical study, 'Commoditisation, Materialism, and Pentecostal Christian Churches', Rufus Olufemi Adebayo note that commoditisation and materialism are factors that play a relational role. He then outlines the changes in the understanding of religious exchange and the economic transaction of the monetary. Understanding of spiritual form of payment, pricing in the traditional marketing (tangible price in this regard) and the shift towards a transactional exchange for divine intervention in the form of miracle, healing, and provision are examined from being major sources of inner spiritual dilemmas to being principal sources of the desire and inspiration underpinning materialism and commoditisation in various Pentecostal churches today. This paper argues that the virtual neglect of some significant characteristics of marketing, such as the exchange process, and pricing from the religious perspective, might affect the church as a non-profit organisation. The study reveals that Pentecostal churches can embrace contradictory concepts of commoditisation, materialism, and spiritualism; and emanate to the social shift as a non-profit sector, but the positive potential inherent to Christianity should be reconciled. Based on current literature trends, the results add that there is a secular exchange of spirituality for materialism, as illustrated in the story of Naaman (2 Kings 5:1-19), thereby problematizing the current South African religious context. The researcher hopes to add to the understanding of the religious exchange, commoditisation, and materialism relationship.

The advent of the new media, particularly social networks and discussion forums, has challenged the dominance of mainstream media by creating a platform for ordinary citizens to frame news objects and set the 
agenda of public discourse. In 'Frames of Corruption in Zimbabwe: A Critical Analysis of Online Public Responses to the Zimdef Corruption Scandal of 2016', Rodwell Makombe and Mpitseng Tladi critically analyse popular responses to corruption among the political elite in Zimbabwe with a specific focus on the Zimdef corruption scandal of 2016. The study is a sequel to a paper published in the Journal of African Media Studies (2018, vol.10. no.1), which focused on how Zimbabwean newspapers framed the Zimdef corruption scandal. This article is different in that it focuses on how newspaper readers (as opposed to journalists) re-presented or re-framed the corruption scandal in their reading of the Zimdef story. While the first paper established that newspapers framed Jonathan Moyo (and by extension ZANU PF) as corrupt and morally bankrupt, this study examines ordinary people's attitude towards corruption among public officials by interrogating their reading of the Zimdef narrative. We collected data from discussion forums of six Zimbabwean newspapers that ran the Zimdef corruption story, namely The Chronicle, NewsDay, The Independent, The Herald, NewsZimbabwe.com, and The Standard. Results of the analysis show that ordinary Zimbabweans do not necessarily subscribe to or consume frames promoted by newspapers. Some respondents, particularly those who belong to minority groups, saw corruption as a way of distributing national resources to the politically and economically marginalised.

'The discourse of politics is believed to be dominated by manipulative rhetoric. In their 'Powerplay in Nigerian Political Visual Discourse: Profiling the All Progressives Congress Party' Kunle Oparinde, Maleshoane Rapeane-Mathonsi, and Gift Mheta, they analyse and discuss the tactical use of discourse resulting in powerplay by the All Progressives Congress (henceforth APC) political party in Nigeria. This is done from a Multimodal Discourse Analysis (MDA) perspective, using the re-contextualisation theoretical model for analysing misrepresentation and manipulation in political discourse. The paper unravels how the APC employs political discourse to exert influence on the masses. Along with support from other linguistic items, the study discovered that the APC is skillful in selecting specific visual and lexical items to achieve their political communication. Thus, this study exposes cases of political artifice as employed by the APC. In total, eleven (11) APC campaign materials were analysed using a purposive sampling method. The paper further confirms the hitherto-stated proposition that discursive strategies are essential in political campaigns and are in some cases employed to attract mass support from the electorate. 
Kanya Padayachee, Darren Lortan, and Savathrie Maistry Titled their paper, 'Rethinking the Integral Education Approach: Ascertaining Curriculum Gaps in the Early Childhood Development Curriculum with Opportunities for Advancing Indigenous Knowledge Values within the South African Context'. The current crisis confronting South Africa is the violence emanating from young people. The increasing evidence of youth violence relating to interpersonal violence and aggression can signal a misguided or ineffectual pedagogical approach. An engagement of literature over the past decade reveals a large proportion of children across the country have experienced some form of violence in school and classroom contexts. The current literature in the field demonstrates that preventive interventions for behaviour and attitude in Early Childhood Development (ECD) can lead to positive self-regulation for greater social responsibility and civic participation. Against this background, this paper highlights the gap(s) in the current ECD curriculum, with a specific focus on incorporating the IK values of Ubuntu. In order to achieve the above aim, this paper employed focus group interviews with ECD staff (comprising supervisors and practitioners) and ECD communities (comprising parents of children, community members, and elders) to determine, inter alia, their understanding of Integral Education (IE), values that are important for children and their views on the current ECD programme. Thematic analysis is used to engage with the research findings. The assumption is made that an IE approach, which incorporates IK with emphasis on Ubuntu, simultaneously develops children's emotional, moral, physical, cognitive, spiritual and cultural capacities and can promote selfregulation and pro-social behaviour. The paper comprises the following: (1) a contextualization of the current curriculum trends and problematising this for the South African context; (2) identifying and discussing the research approach; (3) unpacking the findings emanating from the research approach; (4) critical discussion of the findings, with the proposition of an integral education approach with the IK values of Ubuntu to address the current deficit.

In their paper, 'Mapping Memories through Geographic Information System: The Case of St. Mark's Transdisciplinary Service-Learning Project in District Six, Cape Town' Masilonyane Mokhele and Nicholas Pinfold explore the interconnections between transdisciplinarity and community service-learning, and present ways in which geographic information system and allied methods and tools can be used to preserve and share the socio-spatial history of communities. The initiative that the paper is based on is known as $\mathrm{St}$ 
Mark's Church baptismal community service-learning project, which came into existence when the said church imagined resurrecting the spirit and soul of District Six by visualising its baptismal records. It was anticipated that the visualisation would show where congregants resided when they were baptised, before their community was unceremoniously demolished by the apartheid regime. Participants in the initiative included St Mark's Anglican Church, students (from Cape Peninsula University of Technology and Michigan University), and District Six Museum. During the initiative, a transdisciplinary space organically developed wherein students with different disciplinary backgrounds collaborated towards achieving the aim of the project. So as to draw lessons for future initiatives, the paper particularly focuses on the process followed, instead of emphasising the nitty-gritty details of the product (i.e. a Web map). Towards establishing a holistic socio-spatial history of District Six, it is hoped that the project will be scaled up to include stories and memories of individuals and groups beyond the St Mark's Church congregation.

In a world that calls for multi-skilled graduates, quality and quality assurance present serious and noteworthy challenges for higher education institutions and governments globally. Not only is quality viewed as an elusive concept with varied interpretations, but quality assurance involves multiple stakeholders and role-players whose roles in the setting and regulation of standards are varied and require in-depth understanding. In their study, 'Interactions between Internal and External Quality Assurance in Higher Education Institutions in South Africa - A Case Analysis of Developmental Challenges Facing Academics' Alice Sefora Mkuzangwe and Tennyson Mgutshini explore the range and nature of interactions and engagements between internal institutional quality systems of the university concerned, University X, the relevant professional body, the South African Council for Social Service Professions (SACSSP) and the Council on Higher Education (CHE) with respect to internal and external quality assurance. The interactions and relationships were explored at program level through the internal and external instruments of program reviews and accreditation, using one program, the Bachelor of Social Work (BSW), as an exemplar. An exploratory qualitative design was adopted in which a combination of documents and indepth individual interviews were used to collect data to gain a deeper understanding of both internal and external quality assurance. The content analysis method was applied to secondary data, and thematic analysis was applied on primary data collected through interviews. 
The findings of the study revealed that national policies of the CHE and the policies of the institution, University $\mathrm{X}$, are in alignment, and that there is misalignment between the CHE and professional bodies in general. Furthermore, the findings revealed that there was fragmentation within University $\mathrm{X}$ at policy implementation levels and that the different units responsible for quality assurance operate in silos. This study, therefore, recommends that quality assurance should be viewed as a system of interconnectedness between various stakeholders and role-players, in other words, an all-encompassing process to promote collaboration towards higher levels of quality in higher education.

The study by P.B. Neo Maseko and Mgutshini Tennyson Is titled, 'To be or not to be: Transformative Insights into the Paradox of Using English as the Language of Instruction in South African HE Institutions'. They point out that Universities and other institutions of higher education have been the focus of societal scrutiny in recent years, with many critics arguing that they perpetuate rather than reduce inequalities amongst their learners. This allegation has been aligned by some, they argue, to the fact that literacy and numeracy competencies appear to be class or socio-economically determined and that these differences carry through until graduation and beyond. Significantly, rates of student dropout, attrition and post-graduation employability appear to be directly related to numeracy and literacy. With respect to the latter, literal competence is in effect being used as the yardstick measurement of learners' competence in the language of learning and teaching (LOLT), that is, English. Within South African higher education, the issue of literacy is particularly complicated by the fact that two competing view-points have been articulated namely, that disadvantage for the student can be minimized by offering university education in their mother tongue. The alternate view is based on the notion that the development of competence in English should be a primal focus for all educationalists and may serve as a panacea for the intractable problem of poor student success. A further contention of this alternate view is that English language proficiency has ramifications for students' graduateness and employability prospects. Against this background, the current paper focuses on this paradox as it relates to student success. This analysis specifically considers teaching and learning within Higher Education in the South African context from three languagerelated thematic perspectives namely, (i) cultural identity preservation; (ii) socio-economic mobility and (iii) global citizenry. These perspectives 
encompass the multi-layered paradoxes that form part of the Higher Education landscape in South Africa.

Denzil Chetty's paper titled 'Towards an African Open Learning Revolution: Exploring the Implementation and Role of MOOCs in African Higher Education' focuses on a rethinking of MOOCs (Massive Open Online Courses) within the African continent. Chetty argues that while the past decade has seen an increase in MOOCs, this has largely been a concentrated development in the United States and Europe. While the aim of MOOCs is to make education more accessible, the production of MOOCs in Africa is relatively low. Chetty argues that this relatively low development is due to the high production and hosting costs, the need to focus on global issues at the cost of a localised agenda, and the need to benchmark and compete with universities in the United States and Europe that have historically held the monopoly of knowledge production. Against this background, Chetty explores the development and implementation of MOOCs as part of an African higher education agenda to promote open learning. In order to do this, Chetty draws on a case study of the University of South Africa (Unisa) Open Learning Project. Chetty contextualises the research by unpacking Unisa's MOOC strategy within its Open Distance e-Learning (ODeL) framework, and its vision to be 'the African University shaping the futures in the service of humanity'. Chetty highlights five key areas as part of Unisa's MOOC implementation: (1) MOOC business model; (2) ICT infrastructure; (3) MOOC design; (4) MOOC implementation; and (5) MOOC impact evaluation. In terms of the role of MOOCs in African higher education, Chetty concludes that to truly understand the role of MOOCs in African higher education, its implementation and manadate must be context-driven.

The two articles by Johannes A. Smit, that conclude this issue of Alternation, are respectively titled, 'Neo-liberal Governmentality in post-Nazi Germany's Political Economy Discourse (1945 - 1962)', and 'Anarcho-neoliberal Governmentality in post-WWII American Political Economy Discourse (1945 - mid-1960s).

Pointing to the state phobia of the post-Nazi period, the two articles build further on his research with regard to how we can move beyond Michel Foucualt's notion of knowledge-power, and some seminal thematising perspectives from his researches concerning the world's emergence in the liberal world order, since the mid-1700s (cf. Smit 2019a; 2019b). From governmental discursive contributions on the recently lauched Agreement 
Establishing the African Continental Free Trade Agreement (AfCFTA), Smit critically, and transformatively engage notions of neo-liberal governmentality dating from the post-Nazi period, the 1970s and 19080s, and will as forms of governmentality in the postcolonies of West-Europe, being critically engaged currently.

\section{References}

Department of Education (1997) Education White Paper 3: A Programme for the Transformation of Higher Education. General Notice 1196 of 1997. Department of Education (2001) National Plan for Higher Education in South Africa. Pretoria.

Moyo, T (2018). Development of Human Capital for Industrialisation: Drawing on the Experiences of Best Performers. In Africa Development, Volume XLIII, No. 2, pp. 107-127.

Otenyo, EE (2018). Politics of African Development. In Oxford Biographies.

Available at https://www.oxfordbibliographies.com/view/document/obo9780199756223/obo-9780199756223-0240.xml

(Accessed 01 December 2019.)

Republic of South Africa (1997). Higher Education Act 101 of 1997. Pretoria: Government Printer.

Republic of South Africa (2003). Higher Education Act, 1997 (Act No. 101 of 1997): Merger of Public Higher Education Institutions. Pretoria: Government Printer.

Sen, A (1988). The Concept Development. In Chenery, H; and TN Srinivasan (Eds.) Handbook of Development Economics, Volume 1. Amsterdam Elsevier Science Publishers.

Smit, J.A. 2019a. 'Knowledge-Power' beyond Foucault. Alternation Special

Edition 28: 309 - 334. Available at: https://doi.org/10.29086/25195476/2019/sp28.4a13

Smit, J.A. 2019b. Framing Biopolitics/ Biopower. Alternation Special Edition 28 (2019) 335 - 355. Available at: https://doi.org/10.29086/2519$\underline{5476 / 2019 / \mathrm{sp} 28.4 \mathrm{a} 14}$

Tennyson Mgutshini College of Human Sciences University of South Africa mgutst@unisa.ac.za 
Tennyson Mgutshini, Denzil Chetty \& Vaneshree Govender

Denzil Chetty

College of Human Sciences

University of South Africa

chettd@unisa.ac.za

Vaneshree Govender

Directorate: Research and Postgraduate Support

Durban University of Technology

vanesh@dut.ac.za 